\title{
Assessment of vitreoretinal interface and clinically significant macular edema by OCT and fluorescein angiography
}

\author{
Hany Ali Yahia ${ }^{(1)}$, Sawsan A Shalaby ${ }^{(2)}$, Elham A Hassan ${ }^{(2)}$, \\ Wafaa A Madbouly ${ }^{(2)}$, Nihal Adel Hassan ${ }^{(3)}$ \\ Tanta Hospital of Ophthalmology (1) Ophthalmology department, Faculty of medicine \\ (for Girls), Al Azhar University. ${ }^{(2)}$ Ophthalmology department, Faculty of medicine, \\ Cairo University. ${ }^{(3)}$
}

\begin{abstract}
:
Objective: To assess the changes occurring at the vireoretinal interface with clinically significant macular edema using optical coherent tomography (OCT) and fundus fluorescein angiography (FFA).

Patients and Methods: Ninety nine eyes of 84 patients suffering from macular edema of different etiologies were included in this study. They were divided according to the cause of macular edema into 6 groups. Treatment modalities were done to be evaluated in the follow up. All cases were followed up at regular visits one week, one month, and six months with routine ocular examinations. FFA and OCT changes were determined and evaluated at one month and 6 months after treatment.

Results: In diabetic group (40 eyes), there were 22 eyes with different stages of PVD seen by OCT in comparison to 5 eyes only demonstrated by FFA, ERM seen by OCT of different stages in 14 eyes while in FFA 10 eyes only, In the RVO group (15 eyes), there were 6 eyes with different stages of PVD seen by OCT in comparison to no eyes demonstrated by FFA, In the IGS group (10 eyes), there were 3 eyes with different stages of PVD seen by OCT in comparison to no eyes demonstrated by FFA, In the CNV group (17 eyes), there were 4 eyes with different stages of PVD seen by OCT in comparison to no eyes demonstrated by FFA, ERM seen by OCT of different stages in 3 eyes while in FFA one eye only, In the RP group (10 eyes), there were 2 eyes with different stages of PVD seen by OCT in comparison to no eyes demonstrated by FFA. In the TME group (7 eyes), there were 3 eyes with different stages of PVD seen by OCT in comparison to no eyes demonstrated by FFA, ERM seen by OCT and FFA of different stages in 4 eyes.
\end{abstract}

Conclusions: OCT provided us with valuable information on the retinal morphologic changes associated with ME of different etiologies and analyzing vitreomacular relationship and detecting macular SRD undetectable on biomicroscopy and FFA.

Keywords: PVD (posterior vitreous detachment), ERM (epiretinal membrane), RVO (retinal vein occlusion), IGS (Irvin gas syndrome), CNV (Choroidal neovascularization), SRD (serous retinal detachment), RP (retinitis pigmentosa), TME (tractional macular edema), ME (macular edema). 


\section{Introduction}

The vitreoretinal interface assessment has been greatly aided by the development of of the vitreoretinal interface in the development of macular edema. Intraretinal fluid can accumulate when there is loss of functional integrity in either of the blood retinal barriers and/or loss of an effective RPE pump ${ }^{(2)}$.

The causes of vision impairment in cases with macular edema may be mechanical, optical, or cellular in nature ${ }^{(3)}$.

Pathologic conditions causing macular edema may be, Inflammatory as IGS and uveitis ,retinal vascular diseases as DR and $\mathrm{RVO}$, Choroidal vascular disease as CNV, Drug reactions, Inherited retinal dystrophies as RP, Tractional maculopathies, Retinal detachment, Intraocular tumors, Optic nerve head abnormalities and Idiopathic ${ }^{(4)}$.

The fundus fluorescein angiogram is clinically the most widely available and useful test. It permits study of the circulation of the retina and choroid in normal and diseased states ${ }^{(5)}$.

Optical coherence tomography is a noninvasive, non-contact, trans-pupilary imaging technology (requires only a 3-mm pupil for adequate visualization), allows measurement of retinal thickness from the tomograms, Detection of vitreoretinal interface anomalies that couldn't be detected by biomicroscopy or FFA. It produces crosssectional images (tomograms) of optical reflectivity in the retina in a way like the ultrasound B-scan ${ }^{(6,7)}$

The Spectral Domain OCT has faster data acquisition time and hence improved resolution for the retinal images, with improvements in photoreceptors layer visualization that support more understanding of visual dysfunction in a variety of retinal pathologic features ${ }^{(8)}$.

The aim of this study was to assess the changes occurring at the vireoretinal interface with clinically significant macular edema using OCT as diagnostic and follow optical coherence tomography (OCT). Gaucher et al., ${ }^{(1)}$ supported the importance

up procedure with (FFA), and evaluating additive data taken by OCT over FFA.

\section{Subjects and Methods}

Eighty four patients (99 eyes) suffering from macular edema of different etiologies were included in this study. All cases underwent history taking, complete ophthalmic examination (be best-corrected visual acuity (BCVA), slit lamp examination of the ant. Segment, applanation tonometry, slit-lamp biomicroscopy for assessment of macular edema and the state of posterior hyaloid in relation to the macula, FFA, and spectral domain OCT).

Exclusion criteria included, ocular conditions in which visual acuity would not improve after resolution of macular edema (e.g., foveal atrophy, dense subfoveal hard exudates), cataract, history of treatment for macular edema, history of major ocular surgery, and systemic diseases as chronic renal failure, and myocardial infarction.

According to the cause of macular edema, the treatment was applied and, the cases were grouped into 6 groups:

Group I (Diabetic group): 40 eyes, who received intravitreal injection of $4 \mathrm{mg}$ triamcinolone acetonide followed by laser photocoagulation after 2 weeks.

Group II (RVO group): 15 eyes (8 with BRVO and 7 with CRVO), recieved intravitreal injection of bevacizumab (Avastin) $1.25 \mathrm{mg}$ in $0.05 \mathrm{~mL}$ followed by laser photocoagulation in cases with branch vein occlusion

Group III (Pseudophakic group): 10 eyes received intravitreal injection of $4 \mathrm{mg}$ triamcinolone acetonide.

Group IV (CNV group): 17 eyes. received intravitreal bevacizumab (Avastin) 
Group V (RP group): 10 eyes received oral acetozolamide $500 \mathrm{mg}$ daily.

Group VI (Tractional ME): 7 eyes with macular edema secondary to vitreoretinal interface abnormalities that were referred to vitreoretinal surgeon.
All patients were followed up at regular visits one week, one month, and six months with routine ocular examinations. FFA and OCT changes were determined and evaluated at one month and 6 months after treatment.

\section{Results}

This study was carried out on (99) eyes with CSME of (84) patients and were classified into six groups according to the cause of macular edema (figure, 1 ).

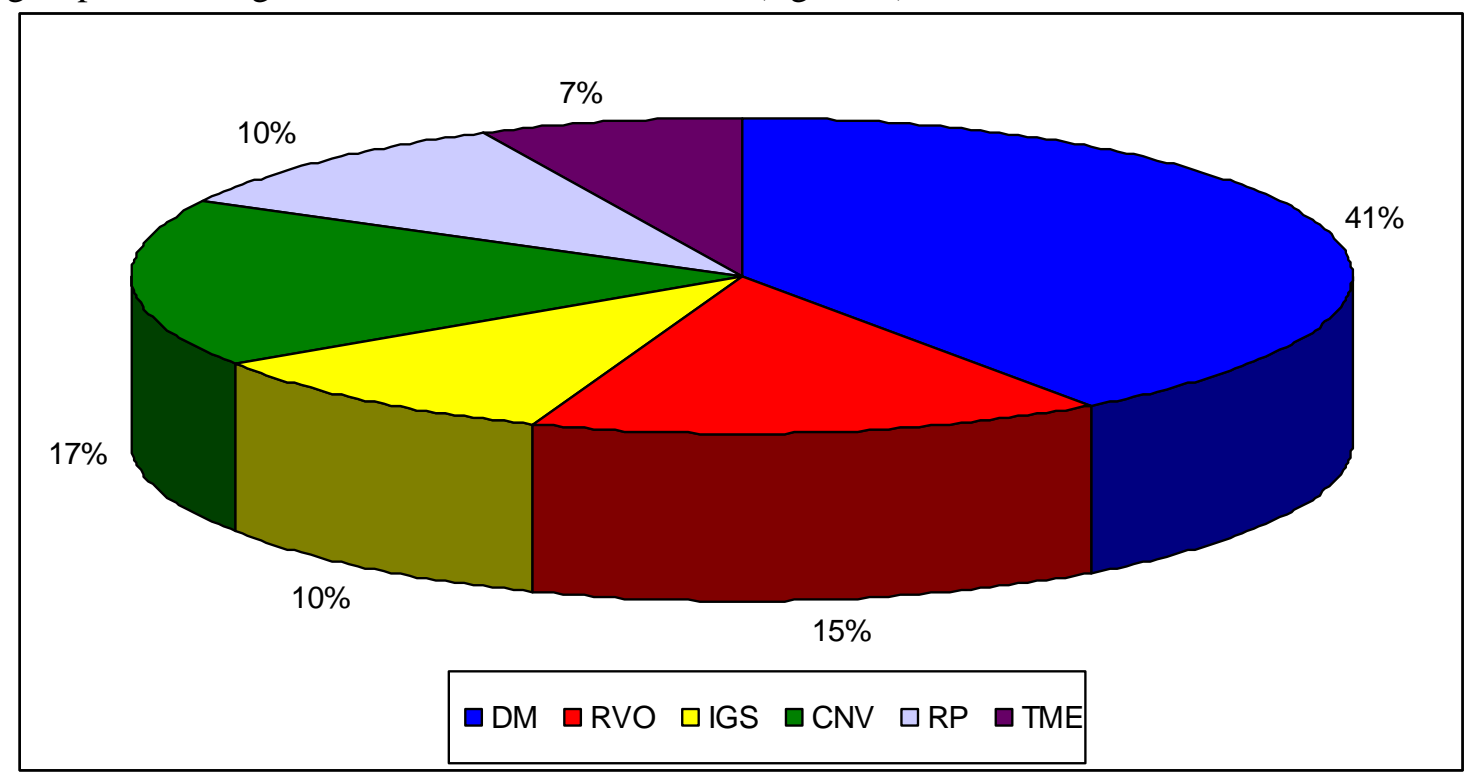

Figure (1): shows percent of eyes in different groups of treatment

All cases underwent complete ophthalmic examination (table, 1), slit-lamp biomicroscopy for assessment of macular edema and the state of posterior hyaloid in relation to the macula), FFA, and spectral domain OCT.

Statistical analysis was performed by the Statistical Package for the Social Sciences software (version 15; SPSS, Inc., Chicago, IL).

For descriptive purposes, qualitative variables were stated using percentage, and quantitative data were reported by mean \pm standard deviation. 
Table (1): Demographic data of patients in different groups:

\begin{tabular}{|c|c|c|c|c|c|c|}
\hline Characteristics & $\mathrm{DM}$ & RVO & IGS & $\mathrm{CNV}$ & $\mathrm{RP}$ & TME \\
\hline No. of patients & 34 & 15 & 10 & 14 & 5 & 6 \\
\hline No. of eyes & 40 & 15 & 10 & 17 & 10 & 7 \\
\hline \multicolumn{7}{|l|}{ Sex of patients } \\
\hline - Male & 18 & 9 & 6 & 13 & 3 & 5 \\
\hline - Female & 16 & 6 & 4 & 4 & 2 & 1 \\
\hline Age(mean+SD) & $\begin{array}{l}60.8 \pm \\
8.169\end{array}$ & $\begin{array}{c}50.2 \pm \\
15.5\end{array}$ & $\begin{array}{c}58.7 \pm \\
15.585\end{array}$ & $\begin{array}{c}72.35 \pm \\
9.899\end{array}$ & $\begin{array}{l}34.0 \pm \\
5.963\end{array}$ & $\begin{array}{c}63.87 \pm \\
7.45\end{array}$ \\
\hline \multicolumn{7}{|l|}{ BCVA(eyes) } \\
\hline - $\quad 6 / 12$ or better & 3 & 1 & 0 & 0 & 1 & 0 \\
\hline - $\quad 6 / 18-6 / 36$ & 16 & 7 & 4 & 7 & 7 & 2 \\
\hline - $\quad 6 / 60$ & 4 & 0 & 5 & 5 & 1 & 2 \\
\hline - $\quad$ Less than $6 / 60$ & 17 & 5 & 1 & 5 & 1 & 3 \\
\hline IOP $($ mean $+/-S D)$ & $\begin{array}{c}15.4 \pm \\
3.1\end{array}$ & $\begin{array}{c}14.8 \pm \\
3.7\end{array}$ & $\begin{array}{c}15.3 \pm \\
2.8\end{array}$ & $\begin{array}{c}15.9 \pm \\
3.2\end{array}$ & $\begin{array}{c}16.8 \pm \\
2.1\end{array}$ & $\begin{array}{c}14.7 \pm \\
2.9\end{array}$ \\
\hline
\end{tabular}

The following proportion was (V/A acuity value $\mathrm{x} 1000$ ) used to describe the ratio of VA and CMT improvement in each group at baseline, one month, and 6 months.

For comparing VA and CMT with baseline values within each group, paired sample t test and mann whitney test were used (table, 2).

$\boldsymbol{P}$ values less than 0.05 were considered statistically significant to control the study.

Table (2):Pretreatment mean central macular thickness and mean visual acuity in all groups:

\begin{tabular}{ccc}
\hline Etiology & $\begin{array}{c}\text { Mean retinal } \\
\text { thickness }\end{array}$ & Mean visual acuity \\
\hline DM & $462.60 \pm 157.556$ & $1.11 \pm 0.536$ \\
\hline RVO & $627.615 \pm 300.433$ & $0.992 \pm 0.403$ \\
\hline IGS & $439.4 \pm 50.762$ & $0.86 \pm 0.241$ \\
\hline CNV & $412.529+162.336$ & $0.941 \pm 0.376$ \\
\hline RP & $339.2 \pm 47.345$ & $0.730 \pm 0.279$ \\
\hline TME & $519.286 \pm 188.656$ & $1.067 \pm 0.543$ \\
\hline Mean & $466.772 \pm 98.602$ & $0.950 \pm 0.140$ \\
\hline
\end{tabular}

Treatment of each group varies according to the etiology of macular edema (figures, 3, 4, 5). Patients were followed up at one month and 6 months after treatment for BCVA, FFA and OCT to detect macular thickening and vitreoretinal interface (table 3, 4, 5). 
Table (3): Central macular thickness and FFA characteristics:

\begin{tabular}{|cc|}
\hline FA characteristics & Mean CRT by OCT \pm SD \\
\hline Focal & $317 \pm 103$ \\
\hline Diffuse & $389 \pm 127$ \\
\hline Focal -diffuse & $438 \pm 141$ \\
\hline CME & $442 \pm 98$ \\
\hline No Ischemia & $349 \pm 129$ \\
\hline Ischemia & $357 \pm 131$ \\
\hline
\end{tabular}

CRT: central retinal thickness, CME: cystoid macular edema, SD: standard deviation.

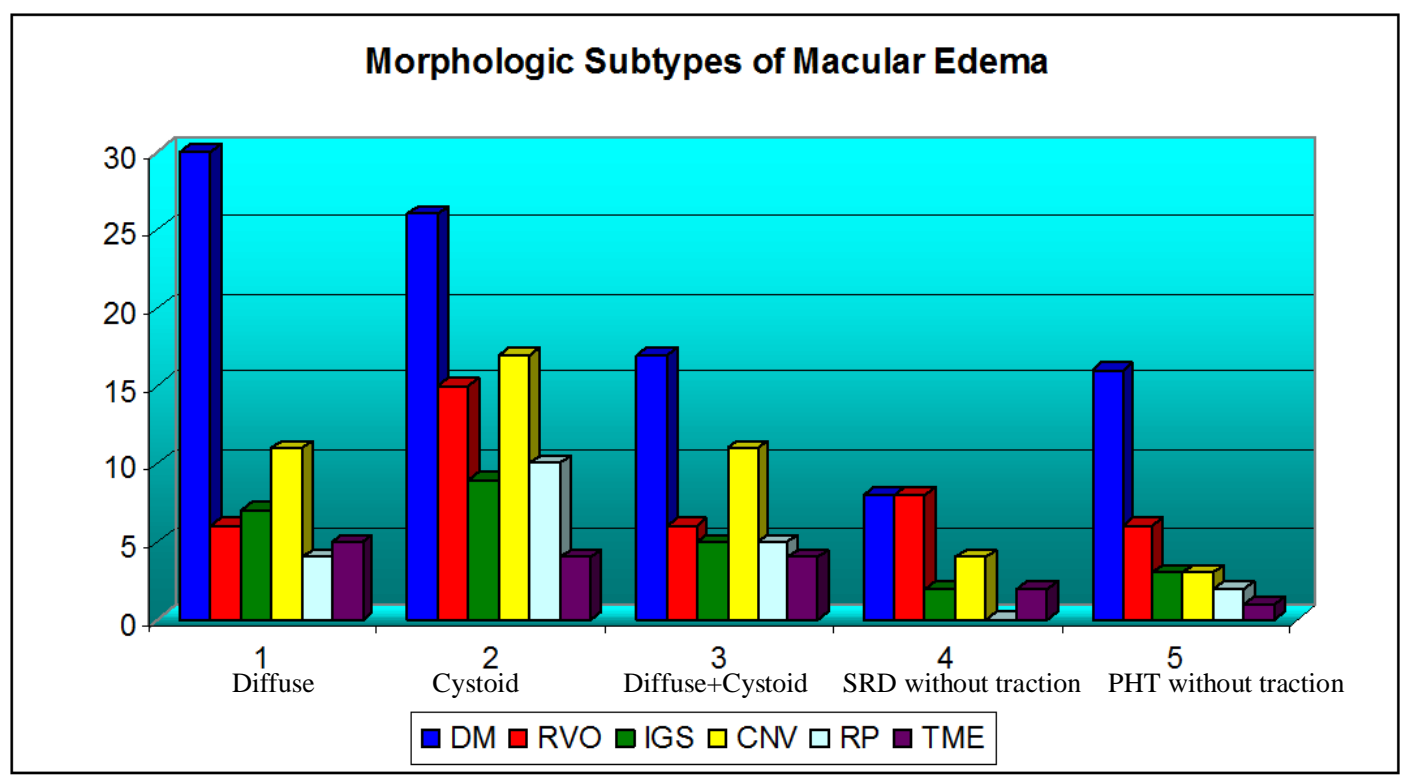

Table (4): Vitreomacular interface abnormalities among different groups seen by OCT in comparison to FFA:

\begin{tabular}{c|c|c|c|c|c|c|c|c}
\hline \multirow{2}{*}{} & \multicolumn{2}{|c|}{ PVD } & \multicolumn{2}{c|}{ ERM } & \multicolumn{2}{c}{ PVD + ERM } & \multicolumn{2}{c}{ VMIA(total) } \\
\cline { 2 - 9 } & OCT & FFA & OCT & FFA & OCT & FFA & OCT & FFA \\
\hline DM & 22 & 5 & 14 & 10 & 6 & 1 & 36 & 16 \\
\hline RVO & 6 & - & 1 & - & - & - & 7 & - \\
\hline IGS & 3 & - & - & - & - & - & 3 & - \\
\hline CNV & 4 & - & 3 & 1 & - & - & 7 & 1 \\
\hline RP & 2 & - & - & - & - & - & 2 & - \\
\hline TME & 3 & - & 4 & 4 & 2 & - & 7 & 4 \\
\hline Total & 40 & 5 & 22 & 15 & 8 & 1 & 62 & 21 \\
\hline
\end{tabular}


PVD: posterior vitreous detachment, ERM: epiretinal membrane, VMIA: vitreoretinal interface abnormalities.

Table (5): The standardized changes in macular thickening (SCMT):

\begin{tabular}{cccc}
\hline Etiology & $\begin{array}{c}\text { Macular } \\
\text { thickening at } \\
\text { baseline }\end{array}$ & $\begin{array}{c}\text { Macular } \\
\text { thickening at 6 } \\
\text { months }\end{array}$ & $\begin{array}{c}\text { The standardized change in } \\
\text { macular thickening (SCMT): }\end{array}$ \\
\hline DM & 448.1 & 264.050 & 0.80 \\
\hline RVO & 627.615 & 316.125 & 0.76 \\
\hline IGS & 439.4 & 274.1 & 0.75 \\
\hline CNV & 412.529 & 309.824 & 0.55 \\
\hline $\boldsymbol{R P}$ & 339.20 & 222.30 & 0.92 \\
\hline
\end{tabular}

The standardized change in macular thickening (SCMT):

$\mathrm{SCMT}=$ [actual change] $/$ [potential change]

$=[$ initial thickness - final thickness $] /[$ initial thickness $-(X) \mu \mathrm{m}]$

$(\mathbf{X})=$ normal retinal thickness by OCT 

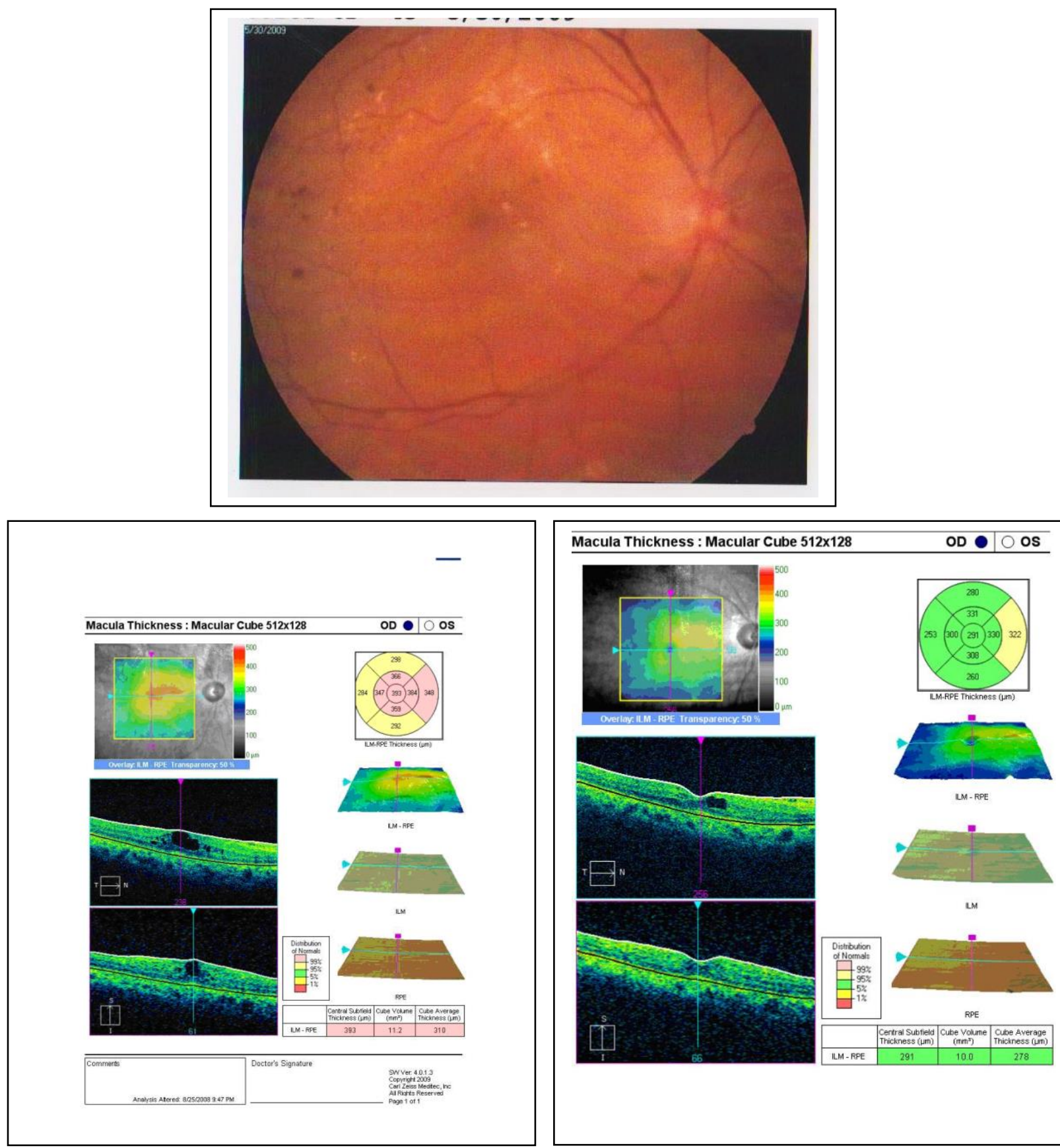

significant diabetic macular edema: (top) fundus photography shows cystoid macular edema with exudates, (bottom left) OCT before treatment, and (bottom right) OCT after 6 months of treatment. 


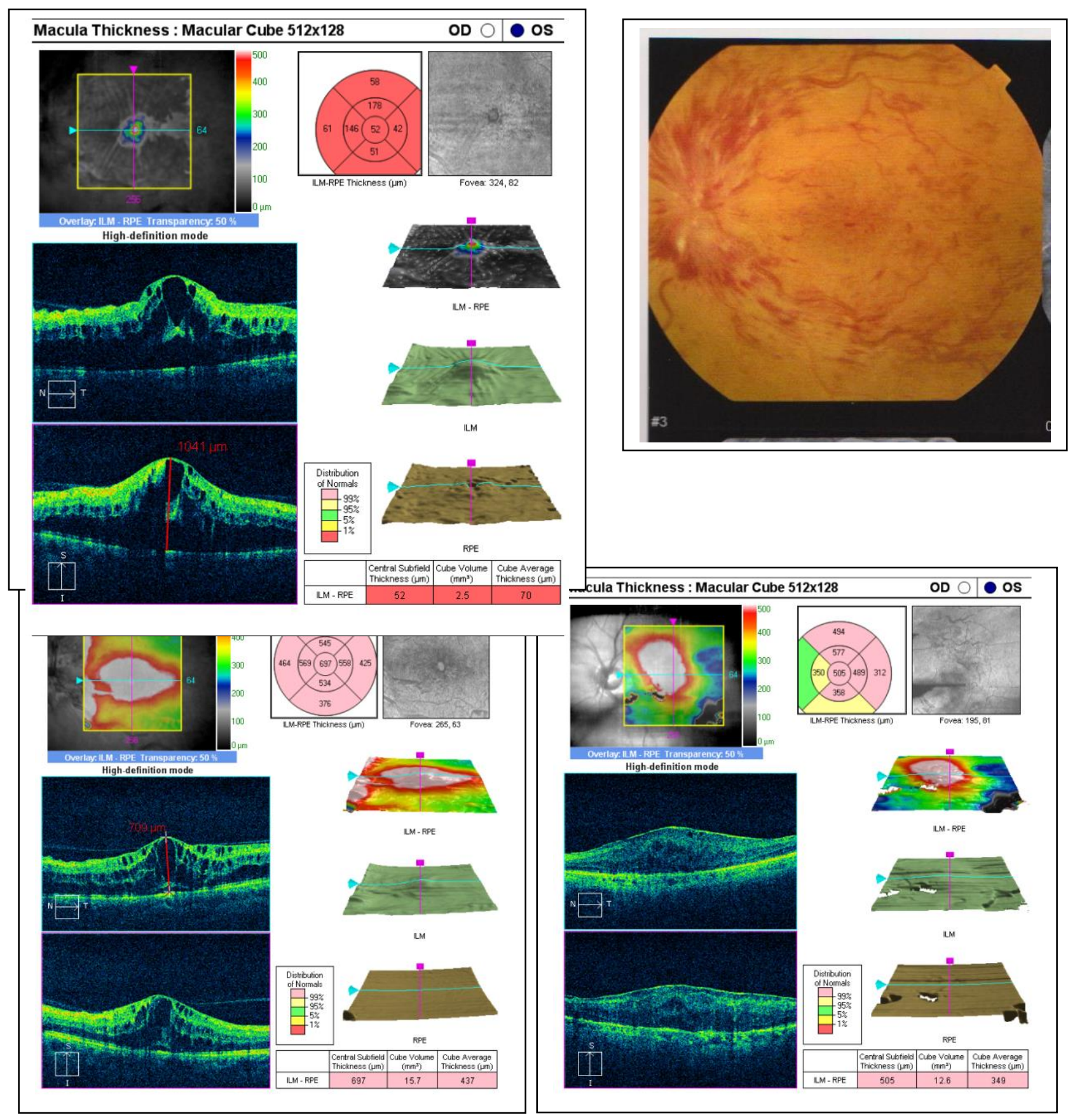

Figure (4): A case with nonischemic CRVO: (top left) OCT of Lt eye shows large cystic spaces with $S R D$, (top right) fundus photography shows CRVO with cystoid macular edema, (bottom left) OCT after 4 weeks of treatment, (bottom right) OCT image after 6 months of treatment. 

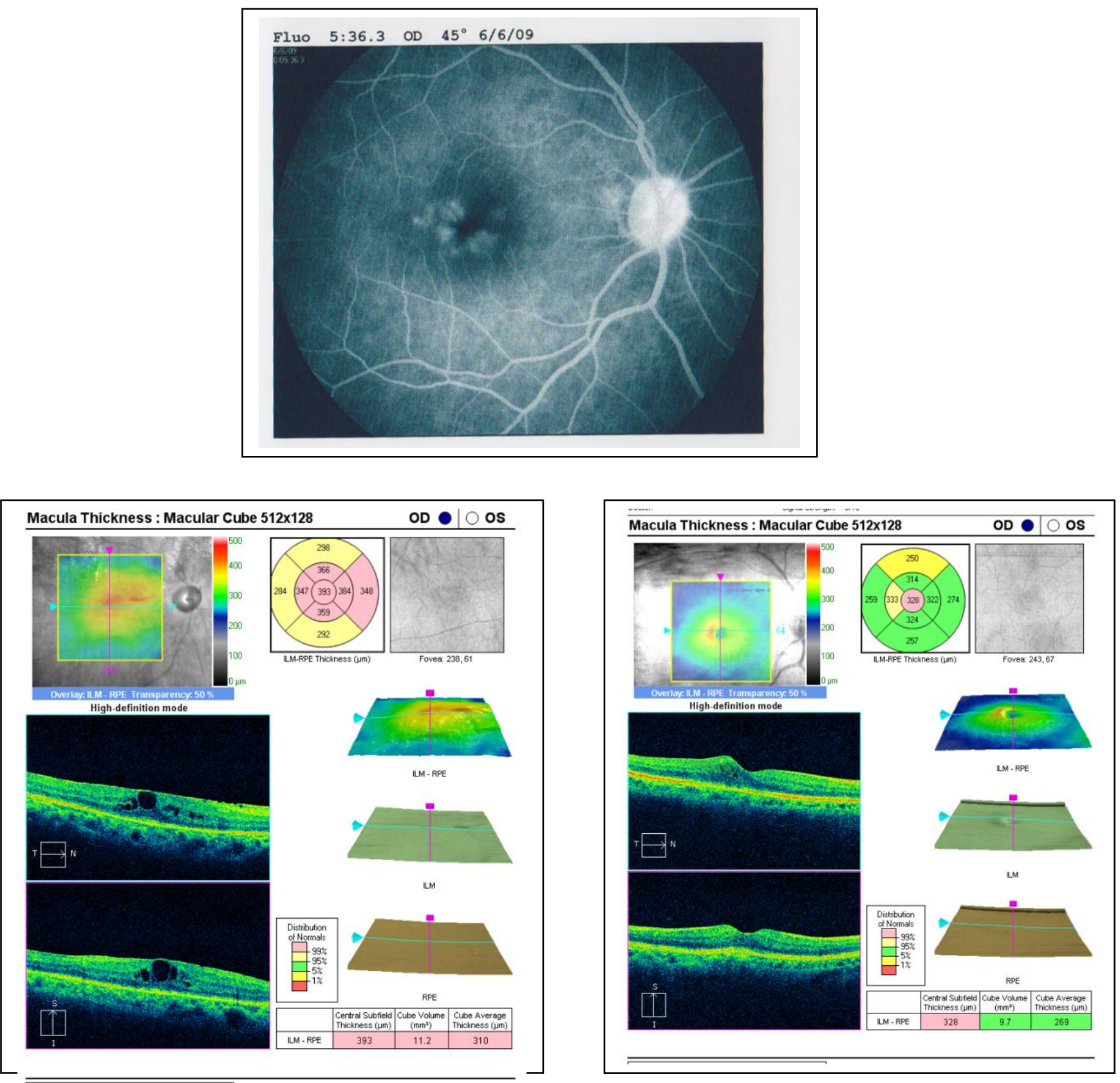

Figure (5): A case with clinically significant pseudophakic macular edema: (top) fundus photography shows clinically significant macular edema in pseudophakic patient, (bottom left) OCT image before treatment, (bottom right) OCT image after 6 months of treatment.

\section{Discussion}

OCT is particularly useful for analyzing vitreoretinal relationships and visualizing vitreoretinal adhesions (9). In this study, the posterior hyaloid was visible on OCT in $40 \%$ of the eyes; the role of the vitreous in the development of ME remains controversial.
The vitreous might indeed play a role in the pathogenesis of diabetic ME by exerting traction on the macula during perifoveolar posterior vitreous detachment: thus, this study found more cases of perifoveolar detachment among patients with diabetic ME than in ME of other etiologies and this is matching with the results by Gaucher et al. ${ }^{(1)}$. 
FFA is known to be a sensitive method for the qualitative assessment of cases with macular edema. In this study SRD was more frequent in cases of $\mathrm{ME}$ associated with vein occlusion $(46 \%)$ than in cases of diabetic ME $(32 \%)$. In agree with Spaide et al. ${ }^{(10)}$ reported a $43 \%$ prevalence of SRD in a series of ME because of vein occlusion, while others ${ }^{(11,12)}$, reported a $15 \%$ and $21 \%$ prevalence, respectively, in cases of diffuse diabetic ME

We found a significant correlation between central macular thickness and VA in patients with pseudophakic, BRVO and diabetic ME, in agree with many authors ${ }^{(11,13)}$. However, others ${ }^{(14,15)}$ found a poor correlation in ME combined with uveitis or retinitis pigmentosa.

CME was detected with OCT in 80 eyes $(80 \%)$ in the study, 30 eyes $(30 \%)$ )of which was not detected during slit-lamp biomicroscopy with a +90D lens and 35 eyes $(35 \%)$ of which was not found during angiography. This is a striking finding, demonstrating the importance of OCT in the detection of foveal changes which are not evident clinically and angiographically. The great discrepancy between FA and OCT could also be the result of a masked cystoid staining pattern in eyes with severe focal and diffuse leakage.

We have demonstrated serous foveal detachment in 22eyes of total 99 eyes (22\% of cases) where it was not detected during clinical examination. This is a very important finding which may explain the cause of unexplained visual loss in patients with diabetic maculopathy. On the other hand, serous foveal detachment determined with OCT was reported in $15 \%$ of diabetic patients in other studies $(5,16)$.

Cystic spaces were more commonly found in the outer retina, as Otani and Kishi (17) studied 59 eyes with DME by OCT and stated that cystoid macular edema was located mainly in the outer retinal layers. This study stated that cystoid macular edema was located mainly in the outer retinal layers in 53 eyes of 80 eyes with CME.
OCT was significantly superior to biomicroscopy and FFA in detecting such vitreomacular interface abnormalities (VMIA) as OCT detected VMIA in 62 eyes in comparable to FFA in 21 eyes. This supports the finding of Gallemore et al. ${ }^{(9)}$, who reported that OCT was on average three times more sensitive than biomicroscopy in detecting vitreoretinal adhesions associated with a variety of macular diseases.

OCT superiority in this study was more significant in eyes with NPDR as compared with those with PDR, perhaps because in PDR, ERMs and areas of vitreoretinal adhesions tend to be denser and generally easier to recognize clinically.

The OCT results described here may be important for several reasons such as eyes with DME are increasingly considered for pharmacologic or surgical therapies as alternatives to laser photocoagulation, the findings of this study underscore anatomic factors that may make patient selection more specific. For example, eyes with DME and evidence of vitreomacular traction in theory may benefit more from vitrectomy than eyes with DME without traction. Clinical support for this was given by a study where vitrectomy was found to be beneficial in eyes with diffuse DME and vitreomacular traction but not in edematous eyes without traction ${ }^{(18)}$. So, OCT may be of value in the early diagnosis of traction in such eyes. In addition, OCT-guided identification of eyes with and without VMIAs may help in understanding some reasons for response or lack of response to pharmacologic therapies for eyes with DME. Furthermore, OCT allows for detection of subclinical macular detachment associated with VMIA that may be missed otherwise.

OCT provided us with valuable information on the retinal morphologic changes associated with ME of different etiologies and analyzing vitreomacular relationship and detecting macular SRD undetectable on biomicroscopy and FFA.

However, FFA is still essential for the assessment of the foveal perfusion state which cannot be demonstrated with OCT. 
After an initial FFA, OCT seems to be a useful tool in the follow-up of the effectiveness of treatment modalities of macular edema. In conclusion, the two imaging modalities, OCT and FFA provided a more comprehensive picture of the pathophysiologic mechanisms of macular edema.

\section{References}

Gaucher D, Tadayoni R, Erginay A, Haouchine B, Gaudric A and Massin P.: Optical coherence tomography assessment of the vitreorela face in diabetic macular edema. Am J Ophthalmol 2005; 139:807-813?

Catier A, Tadayoni R, Paques M, Erginay A, Haouchine B, Gaudric A and Massin P. : Characterization of macular oedema from various aetiologies by optical coherence tomography.Am $J$ Ophthalmol 2005; 140: 200-206.

Gardner TW. : Current strategies and challenges in the management of diabetic retinopathyAdvanced studies in ophthalmology 2005; 2: 14-19.

Johnson MW. : Etiology and treatment of macular edema. Am J Ophthalmol 2009; 147:1121 ?

Hee MR, Puliafito CA and Wong C.: Quantitative assessment of macular edema with optical coherence tomography.Arch Ophthalmol 1995; 113: 1019-1029.

Drexler W.:Ultrahigh-resolution optical coherence tomography [review].J Biomed Opt 2004; 9(1):4774.

Van Velthoven MEJ, Faber DJ, Verbraak FD, Van Leeuwen TG and De Smet MD. : Recent developments in optical coherence tomography for imaging the retina. Progress in Retinal and Eye Research 2007; 26: 57-77.

Kiernan Df, William F. Mieler, And Seenu M. Hariprasad : Spectral-domain optical coherence tomography: a comparison of modern highresolution retinal imaging systems. $A m \quad J$ Ophthalmol 2010; 149: 18-31
Gallemore RP, Jumper JM, McCuen BW, Jaffe GJ, Postel EA and Toth CA. : Diagnosis of vitreoretinal adhesions in macular disease with optical coherence tomography. Retina 2000; 20:115-120.

Spaide RF, Lee JK, Klancnick JM and Gross NE.: Optical coherence tomography of branch retinal vein occlusion. Retina 2003; 23:343-347.

Otani T, Kishi S and Maruyama Y.: Patterns of diabetic macular edema with optical coherence tomography. Am J Ophthalmol 1999; 127:688693.

Kang SW, Park CY and Ham DI. : The correlation between fluorescein angiographic and optical coherence tomographic features in clinically significant diabetic macular edema. Am $J$ Ophthalmol 2004;137:313-322- Suzuma K, Kita $\mathbf{M}$ and Yamana T. : Quantitative assessment of macular edema with retinal vein occlusion. Am J Ophthalmol 1998;126:409-416.

Hirakawa H, Iijima H, Gohdo T and Tsukahara S.: Optical coherence tomography of cystoid macular edema associated with retinitis pigmentosa. Am J Ophthalmol 1999;128:185191.

Antcliff RJ, Stanford MR and Chauhan DS.: Comparison between optical coherence tomography and fundus fluorescein angiography for the detection of cystoid macular edema in patients with uveitis. Ophthalmology 2000; 107:593-599.

16- Toth CA, Narayan DG and Boppart SA. : A comparison of retinal morphology viewed by optical coherence tomography and by light microscopy. Arch Ophthalmol 1997;115(11):1425-1428.

Otani T and Kishi S.: Correlation between optical coherence tomography and fluorescein angiography findings in diabetic macular edema. Ophthalmology 2007;114:104-107.

Massin P, Duguid G, Erginay A, Haouchine B and Gaudric A.: Optical coherence tomography for evaluating diabetic macular edema before and after vitrectomy. Am J Ophthalmol 2003;135:169 177 


\section{تقييم السطح البيني للشبكية والجسم الزجاجي لحالات ارتثاح ماقولة العين باستخدام تصوير قاع العين بصبغة الفلورسين والمسيح المقطعي الضوئي المترابط للعين}

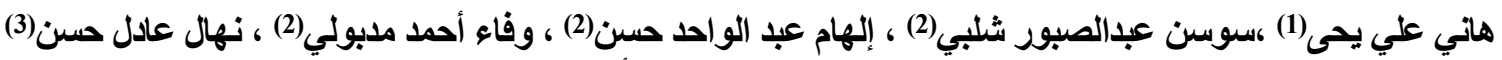

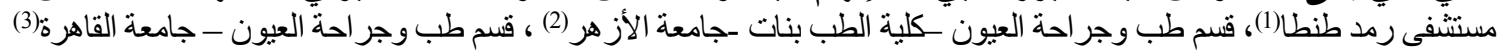

يعتبرارتثاح ماقولة العين أحل أهم الأسباب لضعف الإبصاروقد وجد أنها تحدث مع كتير من الأحوال المرضية

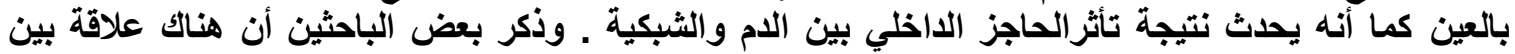

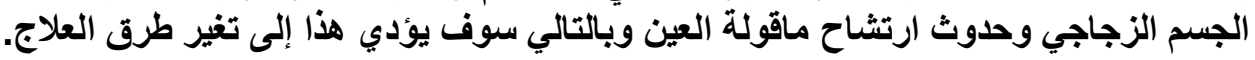

تقلييم السطح البيني: للثبكية والجسم الزجاجي وارتثاح ماقولة العين بواسطة استخام تصوير قاع العين بصبغة الفلورسين و المستـح المقطعي الضوائي المترابط للعين.

تم اختيّار تسعقة وتشتعون عينا لأربعة وتمانين مريضا يعانون من ارتثاح ماقولة العين المؤثرة اكلينيكيا وقد تم

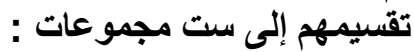

المرضموعة المصابين بارتثاح سكري بثبكية العين مع ارتثاح ماقولة العين المؤثر اكلينيكيا وعددهم أربعون عينا

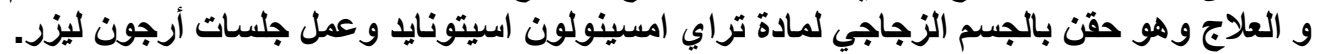

المرضموعة الثانبة:

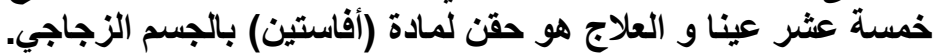

المجموعة الثالثة:المرضى المصابون بارتثاح ماقولة العين بعد عمليات إزالة البيضاء وعددهم عشرة عيون و العلاج هو حقن لمادة تراي امسينولون اسيتونايد بالجسم الزجاجي.

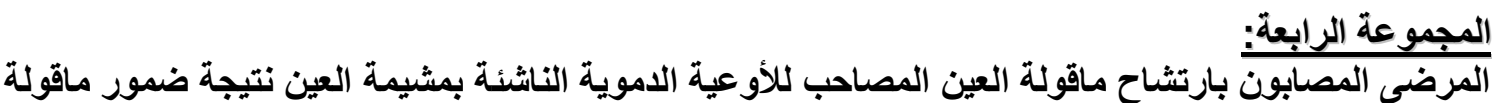

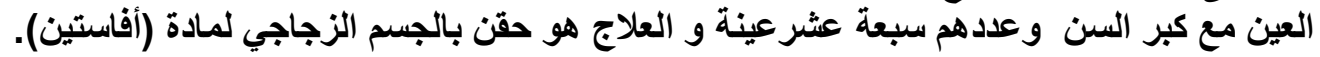

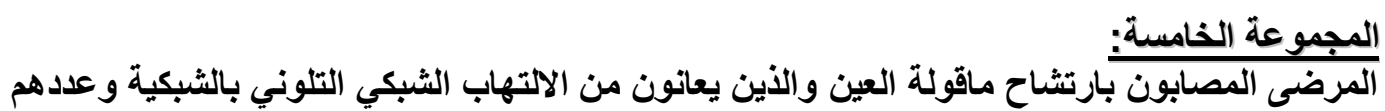
عشرة عيون و العلاج دو ائي و هواستخدام أقراص مادة العند (اسيتازولاميد).

المرضمى المصابون بارتثاح ماقولة العين الناتج عن خلل بالسطح البيني بين الثبكية والجسم الزجاجي و وعددهم سبعة عيون المبارن 


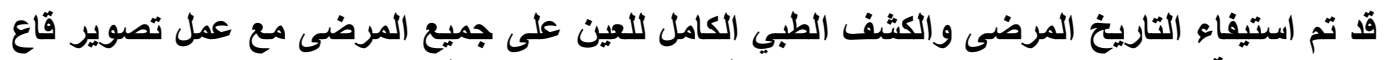

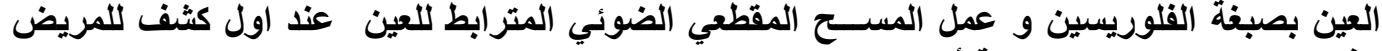
وفي المتابعات عند شهر وستة أشهر.

النتائج:-

-- أظهرت الدراسة حدوث تحسن ملحوظ في سمك ماقولة العين بعد تلقي العلاج المكاج

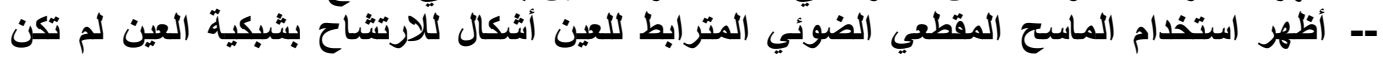

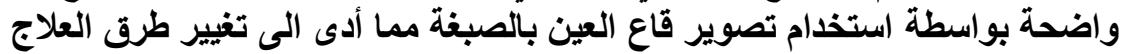

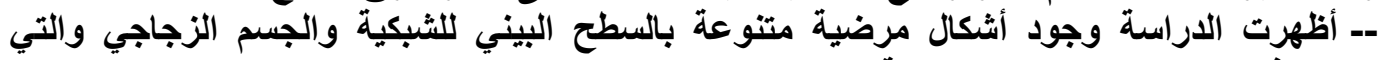
تساعد في تحديد نوع العلاج لكل حالة.

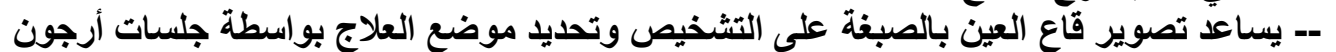

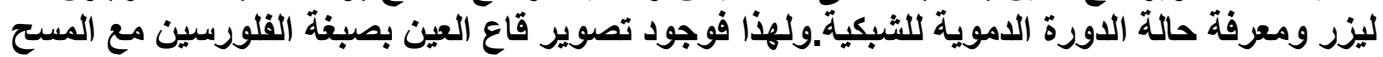

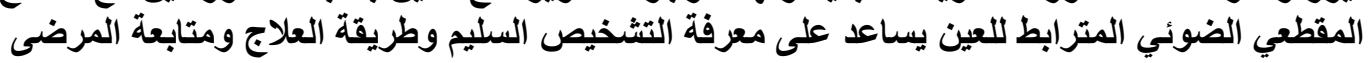
ومدى استجابتهم للعلاج. 